\title{
Revised unit price practice in Turkish construction works
}

\author{
S. Bayram* \\ Erciyes University, Department of Civil Engineering, Kayseri, Turkey
}

\begin{abstract}
In Turkey, for the unit price bidding construction works based on Public Procurement Law, revised unit price is used in case of purchasing too much over the anticipated quantity in the bidding letter. In this context, the revised unit price is applied to the related work item in case of more than $20 \%$ quantity increase also with this increase should be more than $1 \%$ of the contract price. The uncertainty of how to make the revised unit price calculation is clearly defined by a formula. The basic logic in the revised unit price application is to reduce the expected benefit of the relevant work items in terms of the contractor in case of unexpected increase in the quantity of work items. In the revised unit price practices, there may be various disputes arising from the fact that contractors and/or employers cannot possess the principles of implementation. In this study, the revised unit price dispute between the employer and the contractor was discussed. Advantages/disadvantages of the applied revised unit prices in a sewage construction work; case file in the Basic Commercial Court in Kayseri, Turkey was investigated in terms of employer and contractor.
\end{abstract}

\section{Keywords}

Bidding; Construction works; Revised unit price; Sewage

Received: 06 December 2018; Accepted: 28 December 2018

ISSN: 2630-5771 (online) () 2018 Golden Light Publishing All rights reserved.

\section{Introduction}

Construction works can direct the economies of the emerging countries. Tendering procedures of the construction works also play a significant role in preventing wastage of the public resources. The basic principles of the 'Public Procurement Law' (Law no: 4734, hereinafter PPL), which is valid since the year 2003 in Turkey, are efficient use of resources by meeting the requirements timely and under proper circumstances. The reality on the other hand is that the quantities of various workitems may differ during the contract process by its nature. These changes are generally attributed to; unforeseen circumstances, changing conditions, mistakes in the construction process [1].
Work change (increase/decrease of work) is defined as performing the work with the price which is above/below the contract value. In other words, it is the change of the initial contract value to be paid to the contractor [1]. The public employers can get the same contractors to work their changing requirements within the framework of the work change provisions. The payment of the contractor can be also made within this scope.

There are two main legal regulations regarding the change of the work as;

- The provision of the Article 24 of the 'Public Procurement Contracts Law' (Law no: 4735, hereinafter PPCL), which has been simultaneously valid with the PPL; in case any work increase is inevitable due to unforeseen

\footnotetext{
Corresponding author

Email: sbayram@erciyes.edu.tr
} 
reasons, provided that; (a) work increase is kept within the project subject to the contract; $(b)$ it is not technically and economically possible to separate additional work from the main contract without burdening the contracting entity; the contracting entity may have the same contractor perform the work increase up to the amount of $10 \%$ of the main contract's price in turnkey lumpsum works contracts and up to the amount of $20 \%$ of the main contract's price in unit price goods, services and works contracts in accordance with the provisions specified in the original (main) contract and tender documents except the provisions on contract duration.

- The provision of the Article 22 of the 'General Terms and Conditions of Construction Contracts' (GTCCC), which has been published to specify general principles of construction works based on PPCL; the prices of the additional works to be made under the contract shall be paid to the contractor based on the new unit prices determined together with the contractor.

However particularly where the work increase, and decrease are experienced together, the employers frequently practice the 'application of the other work items rather than the abandoned work item'. This practice generally hosts serious risks and/or public losses [2]. Therefore, although it has been controversial, the 'revised unit price' practice has been accepted in construction works to reduce the aforementioned risks and/or public losses. 'Revised unit price' indicates the change(s) on the contracted unit price. Although there are different types of contracts in construction works based on the PPL, revised unit price can only be implemented on the 'unit price bidding' construction works. Substantially, in Turkish public construction works, turnkey lump-sum bidding based on the 'application project' has generally begun to be used following the effectuation of the PPL. However, in various circumstances of the PPL mentioned below, unit price bidding can be requested by the public employer [3];

- Through 'preliminary design' or 'detailed design' in which technical and financial characteristics cannot be determined due to uniqueness and complexity,

- Through 'preliminary design' or 'detailed design' in which there is not enough time for the 'application project' due to natural disasters,

- Through 'detailed design' in all kinds of repair works,

- Through 'detailed design' for the necessity of land and soil investigations at different stages during construction and/or non-completion of the 'application project' before the tender due to the possibility of route and/or zoning changes.

The priority of the revised unit price practice is to avoid public losses in case of purchasing too much over the anticipated quantity in the bidding letter [4]. In this context, the revised unit price can be applied to the related work-item in case of more than $20 \%$ quantity increase for that work also with this increase should be more than $1 \%$ of the contract value [4]. Note that it is necessary to provide these two conditions together. In other words, the revised unit price is not a 'deduction', but a method used to determine the price to be paid to the contractor for the work increase [3]. Thereby the contracted unit price related to work-item should be revised and the contractor payment should be made over the revised unit price for the exceeding from $20 \%$ increase. Such uncertainty of how to make the revised unit price calculation is clearly defined by a formula [5];

$\mathrm{R}=\mathrm{F} \times[1-(\mathrm{A} \times \mathrm{F}) / \mathrm{S}]$

Where; $S=$ contract value (in Turkish Liras, €), $F=$ contracted unit price of the related work-item (£/unit), $A$ = quantity increase of the related workitem (meters, square meters etc.), $R=$ revised unit price (€/unit).

The basic logic of the revised unit price practice is to reduce the expected benefit of the relevant work items in terms of the contractor in case of unexpected increase in the quantity of work items [3]. However, it is argued that the revised unit price practice reflects the distrust of employers and contractors of the construction sector as it cannot be used product purchases or service procurements [6]. In other words, this practice has been implemented 
with the assumption that; if the work items increase excessively, the profits of the contractors will be maximized as a result of the public loss. For this reason, practices such as revised unit price and price variance $\left(V_{m p}\right)$ seem significant during the preparation of progress payments for either nonvictimization of the contractor or non-losses of the employer [7].

For a work item to be re-calculated as revised unit price, its proposal letter attachment should be provided in the 'unit price bidding table'. The main problem starts at this point as; the quantities of the work items presented in the unit price bidding table are not definitive and obligatory. Due to these work items and quantities are not determined based on the application project, they will probably change during construction. As a result of these changes, although they should be provided in the unit price bidding table, there may be changes in the quantities of the work items [8]. Also, it would become necessary to create a work item which is not included in the unit price bidding table [8]. However, the revised unit prices cannot be applied for the work items created with the new unit price $[1,9]$.

The disputes occurred on unit prices are mainly due to the determination of a new unit price, scope of the unit price, and revised unit price [10]. In the revised unit price practices, the main dispute is that the contractors and/or employers cannot possess the principles of implementation [7]. For instance; in the aforementioned Article 24 of the PPCL, no. 4735 , the statement "can be made" it is interpreted as the work increase is totally under the initiative of the employer while the contractor does not have a decision in this matter. For this reason, a frequently encountered situation, in which the contractors should not accept the work increase due to have been awarded at low prices, cannot have a legal basis [1]. Another problem related revised unit price practice is that; revised unit price is inadvertently considered in 'deduction' section instead of 'payments' by the employers during the preparation of progress payments. This application calculates the value-added tax (VAT) amount more than it should be and naturally causes financial losses for the employer even if the revised unit price calculation is correct [3].

In this study, the revised unit price dispute between the employer and the contractor was discussed. Advantages/disadvantages of the applied revised unit prices in a sewage construction work and a case file in the Basic Commercial Court in Kayseri, Turkey was discussed in terms of employer and contractor. Therefore the study is an attempt to answer 'how the revised unit price, a matter of dispute between the employer and contractor due to lack of information, should be accurately implemented to construction works?'.

\section{Previous studies}

Academic studies within the scope of the revised unit price application in the worldwide are quite limited. Shapton [11] examined inflation, forecasting of future prices, contractor markup and factors influencing tender prices in the water and wastewater pipeline capital works in Canadian construction sector. The revised unit prices of standard items were determined by correcting for sharing of general and provisional costs between the standard watermain and sanitary sewer items [11]. In the USA, contractual remedies due to significant changes of the construction works can also vary for from state to state. In California for instance, a forward-priced lump-sum adjustment or recalculation of the affected unit prices to account for increased unit costs principal is in force [12]. Moreover, when the contractor and the employer cannot agree on a revised unit price, it is expressly provided that the employer may require additional quantities above the threshold to be performed on a force account basis.

Another principal difference from state to state in USA is the handling of quantity alterations. Some states allow unit prices to be adjusted when increases/decreases from the estimated quantities exceed a specified percentage [13]. Virginia Specifications indicate that the work items are designated as "major items" and "minor items". For "major items", unit prices are adjusted only for overruns and underruns of greater than $20 \%$ of the original bid quantity. The adjustment is only made 
for the quantity in excess of $20 \%$ of the original bid quantity. For "minor items" on the other hand, adjustments are made only for overruns exceeding $200 \%$ of the original bid quantity and underruns exceeding $67 \%$ of the bid quantity. For the overruns of the minor items, the revised unit price only applies to the quantity in excess of $200 \%$, while for underruns, the revised unit price applies to the entire quantity [14]. New Jersey Specifications on the other hand defines "major item" as any scheduled item in the contractor's proposal which exceeds $10 \%$ of the total price bid. If the quantities are increased/decreased by more than $25 \%$, these major items shall be eligible for price adjustment [13].

Other states of the USA provide unit price adjustments when alterations increase and decrease the total project cost by a specified amount. Kentucky Specifications for example contain that all parties must execute a supplemental agreement covering the altered work if the total cost of the project increases more than $25 \%$. If though, the quantity of a major item is decreased more than $25 \%$, the unit price is adjusted. It can be no greater than $75 \%$ of the original contract amount for that item [15]. Finally, two states as Florida and Carolina, specify no unit price adjustment, but limit the department's right to increase or decrease quantities.

Previous studies within the scope of the revised unit price application in Turkey are also limited. Particularly the past couple of years, tangible attempts have been observed related to the construction industry. Gündüz [1] examined a sample of public service procurement tender based on quantity increases. The awarded bidder and the second-ranked bidder have been compared. It was found that the awarded bidder was served as much as the contract sum. However, in case of the tender prices are given by the second-ranked bidder, a lower price has emerged. Therefore, it was stated that abandoned work items may be abused and these results may cause losses for the employer. Performing revised unit price and work increase implementations as item-based has been recommended [1]. Yilmaz et al. [16] performed a literature review of the unbalanced bidding related to construction works. They have compared the most and the second advantageous biddings on several samples [16]. Anbarc1 et al. [5] argued that Article 22 of the "General Terms and Conditions of Construction Contracts (GTCCC)", titled "Determination of the price of non-contractual works" is only related to price. They have suggested that considering the 'quantity' besides price should be more realistic [5]. Irlayıcı Çakmak [10] identified the primary causes of disputes during the construction stage in the Turkish AEC industry. It was found that the disputes can be categorized into seven main causes as; unit prices, delays and extension of time, contractual matters, variations, contract documents, payments, and other disputes [10]. Ergün [7]; examined the revised unit price and price variance (Vmp) applications of construction works in terms of (previous) State Procurement Law, no. 2886 and (current) PPL, no. 4734. The differences based on the procurement systems were discussed [7]. Polat and Türkoğlu [17] examined the methods for determining the unbalanced bidding in the construction projects. The precautions that can be taken against unbalanced bidding were determined [17].

Literature review indicates that the studies are rather limited with the comparison of the most advantageous biddings or the solution suggestions based on the theoretical decisions. The current study differs by sampling the "applied" revised unit prices in a sewage construction work. A case file as a result of revised unit price dispute in the Basic Commercial Court in Kayseri, Turkey has been discussed.

\section{Method}

Revised unit price application provisions can generally be summarized as follows $[8,18]$;

- The revised unit price can only be applied to the construction contracts those are tendered and contracted with unit price bidding or mixed contracts. The revised unit price application in turnkey contracts is not available.

- The work item that is subject to quantity change must be included in unit price bidding table. The 
revised unit price cannot be applied for a work item that is adscititious or a new unit prices due to the project change etc.

- The quantity increase in the related work item should be more than $20 \%$ of the unit price bidding table, which should be more than $1 \%$ of the contract value at the same time.

- Although there are different practices observed in construction works, revised unit price can be applied to the quantity of excessing $20 \%$.

From a different viewpoint, payment if the quantity increase in the related work item should be more than $20 \%$ is a precaution for the quantity survey abuses [16]. Although the Eq. (1) seems basic and apprehensible, the revised unit price calculations in practice may differ from each other. As an example; a contract price of $€ 1,000,000.00$ is accepted for a tendered construction work. The contract unit price of a work item is $500.00 \mathrm{f} / \mathrm{m}^{3}$, the contracted quantity of the work item is 100.000 $\mathrm{m}^{3}$ while the quantity in practice is $150.000 \mathrm{~m}^{3}$. Revised unit price calculation for this work item can be performed using different approaches as:

1) Quantity increase of the work item terms of percentage:

$(150-100) / 100 \times 100=50 \%>20 \%$ (provision is provided)

Percentage increase of the price of the work item according to the contract value:

$((150-100) \times 500 / 1,000,000.00) \times 100=2.5 \%$ $>1 \%$ (provision is provided)

Revised unit price in Eq. (1);

$R=F \times[1-(A \times F) / S]$

$R=500 \times[1-(50 \times 500) / 1,000,000.00]$

$R=500 \times 0.975$

$R=487.50 € / \mathrm{m}^{3}$

In other words, extra work will be deducted by $£ 12.50$ (2.50\%) from the current unit price. The progress payment to be paid for the work;

$$
\begin{aligned}
& B=(500 \times 100)+(487.50 \times 50) \\
& B=50,000+24,375 \\
& B=£ 74,375
\end{aligned}
$$

Thereby, extra payment of $£ 24,375$ instead of $£ 25,000$ will be made in order to protect the assets of the public. This means a saving of $£ 625.00$ for extra $50.000 \mathrm{~m}^{3}$ work item.
2) $1 \%$ of the contract price is;

$1,000,000.00 \times 0,01=€ 10,000.00$

For the quantity of work item exceeds $£ 10,000$.00, more than $10.000 / 500=20.000 \mathrm{~m}^{3}$ is required.

Since the quantity in the contract is $100.000 \mathrm{~m}^{3}$, the quantity to calculate the revised unit price is; more than $100.000+20.000=120.000 \mathrm{~m}^{3}$

In this way, although the quantity increase of the work item is $50.000 \mathrm{~m}^{3}$, the quantity to be calculated for the revised unit price practice is; $150.000-120.000=30.000 \mathrm{~m}^{3}$. Therefore, the revised unit price calculated in the first approach, $R$ $=487.50 € / \mathrm{m}^{3}$ is valid and the progress payment to be paid for the work;

$$
\begin{aligned}
& B=(500 \times 120)+(487.50 \times 30) \\
& B=60,000+14,625 \\
& B=€ 74,625
\end{aligned}
$$

Thereby, payment of $£ 14,625$ instead of $£ 15,000$ will be made for the work exceeding $20 \%$ in order to protect the assets of the public. This means a saving of $€ 375.00$ for extra $30.000 \mathrm{~m}^{3}$ work item.

3) If the quantity of the work item in practice was $180.000 \mathrm{~m}^{3}$ instead of $150.000 \mathrm{~m}^{3}$ as a different scenario, the revised unit price should be;

$$
\begin{aligned}
& R=F \times[1-(A \times F) / S] \\
& R=500 \times[1-(80 \times 500) / 1,000,000.00] \\
& R=500 \times 0.960 \\
& R=480.00 € / \mathrm{m}^{3}
\end{aligned}
$$

The obtained revised unit price, $R=480.00$ $€ / \mathrm{m}^{3}$ indicates that; as the quantity of the work in practice increases, the revised unit price to be paid to the contractor decreases. In other words, there is an inverse relation between the quantity of the work item and the revised unit price. The details about how to accurately apply the revised unit prices have been discussed on a case file in the next section.

\section{Application}

In this study, a sewage construction work in terms of revised unit price is investigated. The work was performed in Niğde Province of the Central Anatolia Region of Turkey and tendered on May, 2012. The employer and the contractor signed a bidding-unit price contract in November, 2012. The 
contract value was $£ 2,532,975.00$. The amount of work increase was $€ 320,262.19$. The project duration was 450 days and time extension due to the work increase is 54 days. The work was completed in May, 2014. A total of 14 work tasks were defined in the contract. Details are provided in Table 1.

The final cost increase -as mentioned difference- corresponds $12.64 \%$ of the contract value. For the tasks 1 and 8 in Table 1 , the contractual unit prices were revised by the employer. Task 1 is defined as the "construction of sewerage network with diameter of $\varnothing 200 \mathrm{~mm}$. channel pipe" while task 8 is "steam-cured prefabricated inspection chamber with diameter of $\varnothing 200 \mathrm{~mm}$ ”. The dispute between the employer and the contractor begins at this stage. The contractor was notified the employer as the revised unit prices should not be applied. The employer on the other hand claimed that the quantity increase consists of an increase in the 'current tasks' and nothing abnormal. As a result, the contractor files a suit against the employer in the Basic Commercial Court in Kayseri, Turkey. The head of the court soon after requests a technical expert report.

The revised unit price as aforementioned can be applied to the related work-item in case of more than $20 \%$ quantity increase for that work also with this increase should be more than 1\% of the contract value in terms of cost. For the tasks 1 and 8 in this context respectively;

Task 1) Quantity increase of the work item terms of percentage:

$(14,182.69-120.00) / 120.00 \times 100=11,719 \%$ $>20.00 \%$ (provision is highly provided)

Percentage increase of the price of the work item according to the contract value:

$((14,182.69-120.00) \times 38.00 / 2.532,975.00) \times$ $100=21.10 \%>1 \%$ (provision is provided $)$

Table 1. Tasks of the construction work

\begin{tabular}{|c|c|c|c|c|c|c|}
\hline $\begin{array}{l}\text { Task } \\
\text { nr. }\end{array}$ & Unit & $\begin{array}{l}\text { Contractual } \\
\text { Quantity (a) }\end{array}$ & $\begin{array}{r}\text { Produced } \\
\text { Quantity (b) }\end{array}$ & $\begin{array}{r}\text { Contractual } \\
\text { Unit Price } \\
(\mathrm{c} \text { in } €)\end{array}$ & $\begin{array}{r}\text { Contractual } \\
\text { Total Price (axc } \\
\text { in } €)\end{array}$ & $\begin{array}{l}\text { Produced Total } \\
\text { Price (bxc in } € \text { ) }\end{array}$ \\
\hline 1 & $\mathrm{mt}$ & 120.00 & $14,182.69$ & 38.00 & $4,560.00$ & $538,942.22$ \\
\hline 2 & $\mathrm{mt}$ & $32,087.00$ & $26,070.92$ & 39.00 & $1,251,393.00$ & $1,016,765.88$ \\
\hline 3 & $\mathrm{mt}$ & $1,928.00$ & $1,880.09$ & 48.00 & $92,544.00$ & $90,244.32$ \\
\hline 4 & $\mathrm{mt}$ & $2,067.00$ & $2,029.44$ & 49.00 & $101,283.00$ & $99,442.56$ \\
\hline 5 & $\mathrm{mt}$ & 76.00 & 73.41 & 58.00 & $4,408.00$ & $4,257.78$ \\
\hline 6 & $\mathrm{mt}$ & $6,000.00$ & $3,512.63$ & 14.00 & $84,000.00$ & $49,176.82$ \\
\hline 7 & pes & $1,000.00$ & 824.00 & 285.00 & $285,000.00$ & $234,840.00$ \\
\hline 8 & pcs & 3.00 & 297.00 & 750.00 & $2,250.00$ & $222,750.00$ \\
\hline 9 & pcs & 726.00 & 576.00 & 760.00 & $551,760.00$ & $437,760.00$ \\
\hline 10 & pcs & 46.00 & 47.00 & 800.00 & $36,800.00$ & $37,600.00$ \\
\hline 11 & pcs & 39.00 & 40.00 & 840.00 & $32,760.00$ & $33,600.00$ \\
\hline 12 & pcs & 2.00 & 2.00 & 900.00 & $1,800.00$ & $1,800.00$ \\
\hline 13 & pcs & $3,000.00$ & $1,962.00$ & 10.00 & $30,000.00$ & $19,620.00$ \\
\hline \multirow[t]{3}{*}{14} & $\mathrm{mt}$ & $36,278.00$ & $44,291.74$ & 1.50 & $54,417.00$ & $66,437.61$ \\
\hline & & & & TOTAL & $2,532,975.00$ & $2,853,237.19$ \\
\hline & & & & DIFFERENCE & +320 & 2.19 \\
\hline
\end{tabular}


Task 8) Quantity increase of the work item terms of percentage:

$(297-3) / 3 \times 100=9,800 \%>20.00 \%$ (provision is highly provided)

Percentage increase of the price of the work item according to the contract value:

$((297-3) \times 750.00 / 2.532,975.00) \times 100=8.71 \%$

$>1 \%$ (provision is provided)

Although the $20 \%$ sub-limit for the quantity increase comprehensible, $1 \%$ sub-limit for the price increase is complicated since the employers calculate the price of the extra-work based on the contractual unit prices. However, the progress payment for the extra-work is made considering the revised unit price. This means that the calculated extra-work cost will be never paid to the contractor in practice. Revised unit price calculation for the tasks 1 and 8 based on Eq. (1) is presented below;

$R_{l}=38.00 \times[1-((14,182.69-120.00) \times 38.00) /$ $2,532,975.00]$

$$
\begin{aligned}
& R_{l}=29.98 \mathrm{\ddagger} / \mathrm{mt} \\
& R_{8}=750.00 \quad \text { x }[1-((297-3) \quad \text { x } 750.00) / \\
& 2,532,975.00] \\
& R_{8}=684.71 \mathrm{f} / \mathrm{pcs}
\end{aligned}
$$

Sub-limit of $1 \%$ of the contract price is; $2,532,975.00 \times 0,01=€ 25,329.75$

For the quantity of 'Task 1' required to apply revised unit price is the quantity that exceeds $1 \%$ of the contract price (£25,329.75), and not less than $120 \%$ of the quantity of work item $(120 \times 1.20=$ 144 meters) in the contract. However, it should be noted that the calculated revised unit price should be applied to the quantity exceeding $120 \%$ $(14,182.69-144.00=14,038.69$ meters $)$ at the contract. Therefore, considering the revised unit price, $\mathrm{R}=29.98 \mathrm{\xi} / \mathrm{mt}$, the progress payment to be paid for the work;

$$
\begin{aligned}
& B_{1}=(38.00 \times 144.00)+(29.98 \times 14,038.69) \\
& B_{1}=5,472.00+420,879.93 \\
& B_{1}=€ 426,351.93
\end{aligned}
$$

Thereby, payment of $€ 420,879.93$ instead of $€ 533,470.22$ will be made for Task 1 exceeding $20 \%$ in order to protect the assets of the public. This means a saving of $€ 112,590.29$ (26.75\%) for the extra 14,038.69 mt work item.
For the quantity of 'Task 8' required to apply revised unit price is the quantity that exceeds $1 \%$ of the contract price (£25,329.75), and not less than $120 \%$ of the quantity of work item $(3 \times 1.20=3.6$ $\approx 4 \mathrm{pcs}$ ) in the contract. However, it should be noted that the calculated revised unit price should be applied to the quantity exceeding 120\% (297 - $4=$ $293 \mathrm{pcs}$ ) at the contract. Therefore, considering the revised unit price, $R=684.71 \mathrm{f} / \mathrm{pcs}$, the progress payment to be paid for the work;

$$
\begin{aligned}
& B_{8}=(750.00 \times 4.00)+(684.71 \times 293) \\
& B_{8}=3,000.00+200,620.03 \\
& B_{8}=£ 203,620.03
\end{aligned}
$$

Thereby, payment of $€ 200,620.03$ instead of $£ 219,750.00$ will be made for Task 8 exceeding $20 \%$ in order to protect the assets of the public. This means a saving of $€ 19,129.97$ (9.54\%) for the extra 293 pcs work item.

In brief, for these two tasks, the employer pays $£ 629,971.96$ rather than $£ 761,692.22$ and saves a total of $€ 131,720.26$ for these two-extra works, which corresponds $21 \%$ of the actual payment. As aforementioned in Table 1 , the increase corresponds $12.64 \%$ of the contract value for the construction work. The calculated saving can be subtracted from the sum of the produced cost in Table 1.

$£ 2,853,237.19-£ 131,720.26=£ 2,721,516.93$

This means that the revised increase corresponds $7.44 \%$ of the contract value for the construction work.

\section{Results}

In this study, revised unit price practice for a sewage construction work is investigated. The employer revised the unit price of two (tasks 1 and 8) of the 14 tasks for the work. However, the quantity increases were $11,719 \%$ and $9,800 \%$ for the tasks 1 and 8 respectively. These increases are absolutely high and should be unexpected. There are two provisions for the revised unit practice as mentioned; more than 20\% quantity increase for that work also with this increase should be more than $1 \%$ of the contract value in terms of cost. These are both sub-limits and however there are no up-limits defined. These excessive increases 
indicate that upper limits for the revised unit price practices are required. The existing practice should not be interpreted as 'unlimited increases' in terms of quantity. We can see on the other hand that, in the procurement process, it is very significant for the employer to determine the realistic quantity of the work items correctly even it is a bidding-unit price contract type. It is the contractor's right to be informed related to the expectation of the employer at early stages. Because the statement of "can be made" at the PPCL, no. 4735 is generally interpreted as the work increase is totally under the initiative of the employer while the contractor does not have an opinion.

Another conflict related to the issue is the revised unit price formula as presented in Eq. (1). The logic of the formula by its nature is; as the quantity of the work in practice increases, the revised unit price to be paid to the contractor decreases. The contractor will naturally demand to get the payment of the extra work over the contract price. Also, the contractor's abuse is not possible since the work increase is totally under the initiative of the employer. There is also a conflict in progress payments. Should the revised unit prices applied to the related work item in each progress payment (as the revised unit price may change) or should they be considered in the final progress payment? It should be considered and updated in each progress payment independently. Therefore, the most realistic calculation should be performed at the final progress payment stage.

As a result, the revised unit price practice in Turkish construction works must be revised and reedited as soon as possible by focusing on the quantity limit alterations. A "major task" can be defined as "the scheduled task which exceeds $10 \%$ of the total price bid' and the "minor task" as the remaining. For these two types of tasks, different provisions can be sought to take into account. For the up-limits to be defined, 'cannot be greater than $75 \%$ of the original contract amount for that task' can be stipulated. Senior administrations should also supervise the arbitrary implementation of the public authority to prevent the abuses. It is clear that the court way for this kind of dispute is time-waste for both sides of the contract.

The goal of this study is to improve the conditions of the revised unit price practice in Turkish construction works. However as the literature review reflects, the number of academic studies on this topic are very small and this study is also expected to be a guide for the countries that adopt the revised unit price practice. For the future studies, the impact of the revised unit price practice can be evaluated considering more samples.

\section{References}

[1] Gündüz, F. Hizmet ihalelerinde mecburi bir öneri: revize birim fiyat veya kalem bazında iş artışı. Yasal Dayanak-İhale ve Mali Mevzuat Dergisi 1 (2014) 19-23.

[2] Revised price application due to quantity increase in construction works (Yapım işlerinde iş artışı nedeniyle revize fiyat uygulamas1). Date of access: 22.01.2018

http://pozitifhukuk.org/hakedis-sureci/yapimislerinde-is-artisi-nedeniyle-revize-fiyatuygulamasi

[3] Yalova Valiliği Çevre ve Şehircilik İl Müdürlüğü, Revize Birim Fiyat Kesintisi Hakedişte Kesintiler Kısmında mı Gösterilir? Date of access: 15.03.2018

http://yalova.csb.gov.tr/revize-birim-fiyatkesintisi-hakediste-kesintiler-kisminda-migosterilir-haber-64073

[4] Başçı, Z. Revize birim fiyat hangi şartlar altında düzenlenir? 2016. Date of access: 10.02.2018. https://www.ampyazilim.com.tr/makaleler/revizebirim-fiyat-hangi-sartlar-altinda-duzenlenir

[5] Anbarcı, M., Türkakın, O.H., Öz, B. Yapım işleri genel şartnamesine göre sözleşmede bulunmayan işlerin fiyat tespiti ile revize birim fiyat ilişkisi. Yap1 Dünyas1, 238-239 (2016) 37-41.

[6] Revize Birim Fiyat Uygulaması: Örnek Çözümlü. Date of access: 22.03.2018.

https://www.malihakem.com/analizler/revizebirim-fiyat-uygulamasi-ornekcozumlu_an439.html

[7] Ergün, S. Issues encountered in revise price and price gap practices on construction work biddings and solution proposals (Yapım işi ihalelerinde revize fiyat ve fiyat farkı uygulamalarında 
karşılaşılan problemler ve çözüm önerileri). Expertise Thesis, ILBANK, Turkey, 2017.

[8] Kemer, M. 4734 sayılı Kamu İhale Kanunu kapsamında yapım işleri örneklerle yaklaşık maliyet hakediş uygulamaları fiyat farkları. Sözkesen Matbaacılık, 83-140, Ankara, Turkey, 2004.

[9] T.C. Bayındırlık ve İskân Bakanlığı Yüksek Fen Kurulu Başkanlığı, (2006). İş Kalemi Miktarlarının Değişmesi. Date of access: 02.04.2018. http://webdosya.csb.gov.tr/turkce/dosya/kararlar/2 006-021.doc

[10] Irlayıcı Çakmak, P. Causes of disputes in the Turkish construction industry: Case of public sector projects. ITU A|Z, 13 (2016) 109-118.

[11] Shapton, B.J. Development of unit price indices and estimating inflation for potable water and wastewater pipeline capital works construction. M.Sc. Thesis, University of Waterloo, Ontario, Canada, 2017.

[12] Wiezel, J.P. The significant change in the character of the work" clause: Uncertain federalism in highway construction contracts. Public Contract Law Journal, 42 (2013) 327-346.

[13] Parvin, C.M., Araps, F.T. Highway construction claims - a comparison of rights, remedies, and procedures in New Jersey, New York, Pennsylvania, and the Southeastern States. 12 Pub. Cont. L.J. 255 (1982).

[14] Virginia Dep't of Highways and Transp., Road and Bridge Specifications, § 104.02 (1978).

[15] Kentucky Dep't of Highways and Transp., Road and Bridge Specifications, supra note 10, § 104.02.

[16] Yılmaz, M., Bakış, A., Dereli, Z.A., Çiçek, C. İnşaat ihalelerinde dengesiz teklif. $8^{\text {th }}$ Engineering and Technology Symposium. 14-15 May 2015, Ankara, Turkey.

[17] Polat, G., Türkoğlu, H. An Investigation on Detection Methods Used Unbalanced Bidding in Construction Projects. $7^{\text {th }} \quad$ Construction Management Congress, 06-07 October 2017, Samsun, Turkey.

[18] Alsaç, Ü. İhale ve sözleşme mevzuatı -soru cevap serisi-9 (İlansız Pazarlık Usulü-Yapım İşlerinde Revize Birim Fiyat), 2017, Date of access: 10.01.2018.

https://tr.linkedin.com/pulse/ihale-ves\%C3\%B6zle\%C5\%9Fme-mevzuat\%C4\%B1soru-cevap-serisi-9-revize-umit-alsac-mpp 